\title{
A Goal Analysis of Alternative Tuna Fishery Arrangements between Indonesia and Japan
}

\author{
Gerald G. Marten, Yoshiaki Matsuda ${ }^{1}$, John Bardach, \\ Salvatore Comitini and Sutanto Hardjolukito
}

Environment and Policy Institute, East West Center, Honolulu, HA. 96848 (U.S.A.)

(Received May 5, 1981; accepted after revision April 26, 1982)

\begin{abstract}
With the advent of extended maritime jurisdictions, new arrangements will be sought between fisheries resource owners and distant-water fishing fleets that may want to share the use of fishery resources. Each party has motives for wanting to exploit the fishery, and each has strengths and weaknesses in doing so. The purpose of this study was to develop a logical process to identify arrangements that are fair and profitable for both parties. As a case study, we examined conflicts and agreements of interest between Indonesia and Japan with respect to arrangements they might have for exploiting Indonesia's tuna. Thirty-seven possible arrangements between the two countries were evaluated by a multinational, multidisciplinary team employing goal analysis, an optimization technique for dealing with multiple objectives. The arrangements differed in the following respects: type of fishing operation (all of them longline, but differing with respect to vessel size and other characteristics); kind of processing (cold storage, canning, or freezer-carrier operations); ownership (Indonesian, joint-venture, or Japanese); base of operation (Indonesia or Japan); participating Japanese sector (small-scale tuna fishermen, medium-scale tuna fishermen, or traders and large-scale fishery companies); and marketing alternatives (fresh fish, frozen fish, or canned-goods markets).

Tradeoffs were examined among eleven goals and constraints that might be involved in negotiating an arrangement: capital investment, return on investment, employment, foreign exchange earnings, and technology transfer for Indonesia; capital investment, return on investment, employment, tuna supply, fishermen's profits, and traders' profits for Japan.

This study found many points of agreement of interests between the two countries, to the extent that they can share in efficient and profitable fishing, processing, and marketing operations where both parties can enjoy the benefits. In particular, freezer-carrier operations combined with Indonesian-based fishing offer many advantages over the recent fee fishing arrangement. Genuine conflicts of interests also were found in tradeoffs between employment and operating costs and in how the ownership and profits of the operations are shared
\end{abstract}

* Present address: Laboratory of International Marine Policy, Faculty of Fisheries, Kagoshima University, Shimoarata Kagoshima, Japan.

0302-184X/82/0000-0000/\$02.75 (C) 1982 Elsevier Scientific Publishing Company 
between the two countries. Although results are preliminary and require further refinement and validation before they can assist with real fishery negotiations, this approach to exploring new options for bilateral fishery arrangements has great potential and should be pursued to the point where it can be utilized in practice.

\section{INTRODUCTION}

With the advent of extended maritime jurisdictions questions arise about future relationships between fisheries-resource owners and distant-water fishing fleets that may want to share the use of fisheries resources. Both resource owners and distant-water fleets have their own strengths and weaknesses and motives for wanting to exploit the fishery, and each has reasons to justify its position (Bardach and Matsuda, 1980; Aprieto, 1981).

Despite the efforts of some nations to distinguish highly migratory species such as tuna from other species shared by neighboring coastal states, many developing nations regard tuna as their own property and have initiated negotiations with distant-water fishing fleets concerning the exploitation of tuna within their jurisdiction (Masuda, 1977). It seems that a major portion of world fisheries will fall under national jurisdictions as a result of the authority that many countries are in the process of asserting over their maritime resources. Ninety percent of the known world fishing grounds are located within 200 miles of one country or another (Morisawa, 1980). As a consequence, distant-water fishing fleets are being increasingly shut off from free access to fish stocks they enjoyed until recently. Distant-water fishing fleets are therefore faced with a problem of overcapitalization and unemployment unless they can retain access to fish stocks they formerly exploited.

If the resource owner is a developing country, it likely has a well-developed artisanal fishery which already exploits the numerous species of its inshore areas, but it may be limited in the technical experience, financial resources, and facilities it can bring to bear on fully exploiting its offshore fisheries. This is particularly so for the highly competitive tuna industry which has developed a sophisticated international network for catching, processing, and marketing the fish. Developing countries stand to gain if they can be involved in the entire process, including marketing of final products.

Because distant-water fleets have a surplus of trained manpower and equipment that a fishery resource owner may lack (Kaczynski, 1979), it seems logical for resource owners, particularly if they are developing countries, to collaborate with distant-water fleets to obtain full benefits from their fisheries. In fact, such cooperative arrangements existed long before 
extended maritime jurisdictions entered the scene, but they have not always been satisfactory. The resource-owning nation often feels itself to be in an economically disadvantageous bargaining position from which it is not getting a fair share of the benefits. Furthermore, its real participation is often marginal and does not lead to acquiring skills and equipment that would allow it to grow beyond its dependence on foreign participation (Djalal, 1978).

On the other hand, the foreign fishing fleet often feels insecure about the relationship because of legal advantages the resource owner may have and the difficulties of depending upon an inexperienced partner in a highly competitive industry. As a consequence, many such joint ventures have failed. Others have been a commercial success, but have continued with inequities leaving one or the other partner dissatisfied with the arrangement (Ouchi and Matsuda, 1980).

Numerous extended maritime jurisdiction tuna-fishing arrangements are currently under negotiation, and even more will arise in the near future. There is therefore a need for a logical process to identify arrangements that are fair and profitable for both parties to encourage an atmosphere of mutual trust for fisheries development. With the object of developing such a process, a small group of fisheries biologists, economists, and lawyers from the United States, Japan, the Philippines, and Indonesia assembled for several months to bring together information on the exploitation of tuna in Southeast Asia, to examine the implications of the information for transnational relations and fisheries-resource management, and to determine the political and economic implications of possible cooperative arrangements for tuna exploitation. The group decided on a joint exercise aimed at evaluating a broad range of possible cooperative arrangements between fisheriesresource owners and distant-water fleets from the point of view of conflicts and agreements of interest between the two parties (Valencia, 1979). Indonesia was chosen as the resource owner and Japan as the distant-water fleet.

It was necessary to restrict the scope of the analysis for practical reasons, and longline fishing of large tunas was selected because of the history of Japanese longline fishing in Indonesian waters. This is not to suggest that tuna longline fisheries are more important than other fisheries (such as purse seining); skipjack tuna, for example, could be particularly important in terms of development potential and significance for future bilateral agreements. The purpose of this exercise, however, was to use tuna longline fisheries to illustrate an analytic approach that could have useful applications for negotiators in a variety of fisheries. 


\section{HISTORY OF TUNA FISHING RELATIONS BETWEEN INDONESIA AND JAPAN}

Before World War II, Japanese tuna vessels occasionally fished the Banda Sea, Flores Sea, Timor Islands area, and the Indian Ocean south of the Sunda Islands (Fig. 1). Research and training vessels also explored coastal areas of Sumatra and the Nicobar Islands (Oamabara, 1962). Although these fishing activities ceased by 1945, they were resumed by 1952 and were extended to the Indian Ocean and the South Pacific Ocean (Masuda, 1963).

In 1957, Indonesia unilaterally declared the archipelagic principle as the basis for the claim over its territorial waters. Japanese tuna vessels had been fishing Indonesian waters without restriction until that time, and Indonesia's determination to enforce its claim led to friction between Indonesia and Japanese fishing interests, especially in the Banda Sea. The Japanese protested to Indonesia in 1957 and again in 1960, claiming traditional fishing rights, but Indonesia held its position and detained a number of Japanese fishing vessels.

Efforts by the two countries to resolve the matter finally resulted in a fee fishing agreement in 1968 between the government of Indonesia and the government of Japan (on behalf of the National Federation of Fisheries Cooperatives of Japan and the Federation of Japanese Tuna Fisheries Cooperative Associations). Indonesia wanted to establish a joint venture because it would imply recognition by Japan of Indonesia's archipelogic claim, but Japan was not interested. Although the fee fishing arrangement represented a partial recognition of Indonesia's claim, Japan was careful not to commit itself to a full recognition of the archipelagic principle. With the payment of a fee the Japanese fishermen were able to maintain their presence in the area and fish more or less as they had in the past. As the arrangement was valid for only one year, it had to be renewed annually, and negotiations often bogged down during renewal. Because the Indonesians were not satisfied with revenues realized from the agreement, they insisted on modifications that the Japanese accepted not only because of the importance of the Banda Sea fishery for the livelihoods of a significant number of people in the Japanese fishing industry, but also because of the importance of Indonesia to Japanese economic activities. The arrangement was renewed five times between 1968 and 1975 and brought about $\$ 147640$ in license fees to the Indonesian government. Indonesia also received \$1929186 in grants and $\$ 7856285$ in the form of credit project aid from Japan during those years (Djalal, 1978). These grants could be viewed in part as an indirect subsidy from the Japanese government to Japanese fishermen, who are a politically powerful force in Japan. Japanese fishermen caught about 40000 tons ( $\$ 20$ million) of tuna from the Banda sea during that period (Japan Fishery Agency, 1970-79). 


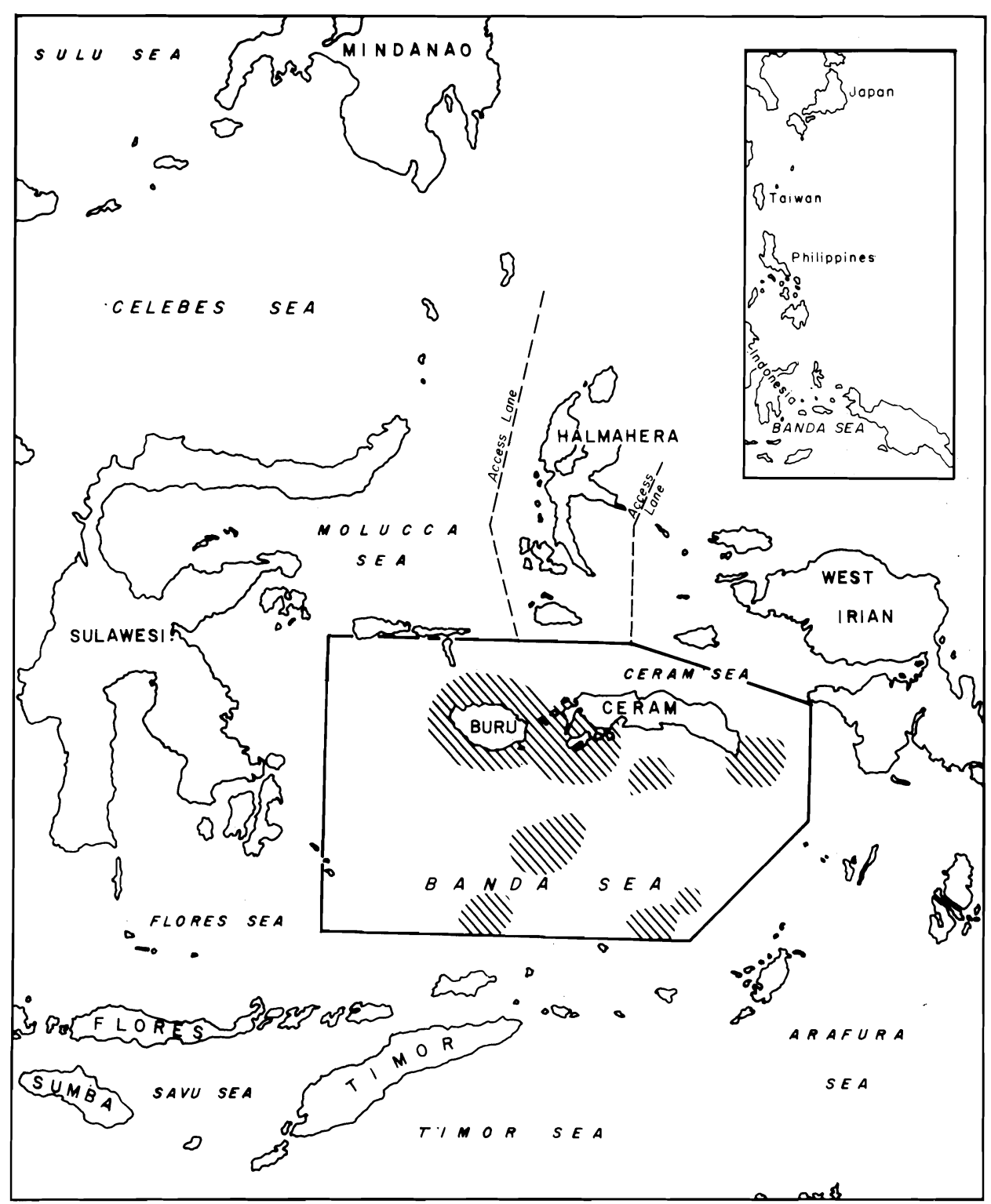

Fig. 1. Area covered by Banda Sea agreements between Indonesia and Japan (1968-1980). The shaded areas were off-bounds to Japanese fishing.

Meanwhile, an Indonesian government longline fleet fishing large tunas was established in 1972 with Japanese assistance in Benoa (Bali) and Sabang (a small island north of Sumatra Island). It possesses 18 modern 90-ton tuna longliners and a cold-storage capacity of 1800 tons. Initially there were 
problems due to lack of knowledge of the tuna migrations and freezer deficiencies, where temperature must be maintained at $-55^{\circ} \mathrm{F}$ to meet standards for sashimi, the highest priced tuna product on the Japanese market.

The Banda Sea agreement was revised in 1975 to include pledges of economic assistance and a profit-sharing system between Indonesia and Japan. According to this agreement, Indonesia received a guaranteed minimum fee or $40 \%$ of the profits from Japanese fishing in the Banda Sea, whichever was greater. However, the profits declared by the Japanese were so low (sometimes negative) that Indonesia did not receive enough to cover administrative costs.

Although a quota was set at 8000 tons per year, the average annual catch was only 3048 tons during 1976 and 1978 (Zimbo, 1979). Up to 100 vessels were permitted to operate under the contract, there were only 23 reporting in 1975-76, 35 in 1976-77, and 35 in 1977-78. During the three-year period of the revised agreement, besides profit-sharing, the Indonesians obtained grants in the form of one training vessel and its equipment valued at $\$ 1.8$ million and a repair shop valued at $\$ 200000$ (Djalal, 1978). The Japanese also provided, through the Overseas Fisheries Cooperation Foundation, training in freezer and vessel equipment use for Indonesian fishermen by the Japanese Federation of Fisheries Cooperative Associations.

The last Banda Sea agreement, based on a catch fee of $3.75 \%$ of the standard landed value at Japanese ports, was established in 1979. Besides a fixed catch quota of 7000 tons per year, restrictions on boat size and number of trips, exclusive fishing rights for Japan, and obligations for in-country training, it required reporting of catches and inspection of boats at Ambon. A significant feature of the arrangement is that it did not allow freezer-carrier mother ships, in the hope that the Japanese woul establish on-shore processing facilities. However, Japanese fishing vessels ended up transporting the fish directly to Japan without a mother ship. Although the last Banda Sea agreement was an improvement from the Indonesian point of view, the fishing activity was economically marginal for Japan, though politically important.

The agreement was not renewed in 1980, apparently because of Indonesia's desire to evolve to a joint venture and the unacceptability of this to Japan. There is also evidence that Japan is reevaluating its former policy of promoting long-distance tuna-fishing in view of recent sharp increases in fuel prices and other operating costs (Comitini, 1971; Hara, 1979). 


\section{METHODS}

The analysis was structured around the idea of evaluating alternative fishery arrangements between Indonesia and Japan with respect to the goals those two countries have when entering into such an arrangement. Our procedure was as follows:

(1) enumerate the goals; (2) list alternative fishery arrangements; (3) tabulate how well the arrangements perform with respect to the goals; (4) evaluate the arrangements.

Each of these steps is elaborated below.

\section{Formulation of goals}

Table 1 lists the goals and constraints of Indonesia and Japan, as identified by the group. An important point to note about Table I is that even the goals of a single country can be in conflict with one another. Not only do conflicting interest groups within the country have conflicting goals (or assign different priorities to the same goals), but a single interest group can have goals which are not mutually compatible. Goal analysis is a way of examining tradeoffs between multiple goals and how the attractiveness of alternative fisheries arrangements changes as the priorities on different goals are shifted.

Some of the goals in Table I were not used in our analysis because of lack of data. The goals that were used are listed in Table II along with the operational definitions that were employed for calculating the goal values of various arrangements.

Japanese perspective. The economic impacts of 200-mile limits on Japanese tuna and skipjack fisheries are substantial because $48 \%$ of the tuna and $41 \%$ of the skipjack catches by the Japanese fishing fleet in 1977 came from within 200 miles of the coasts of 54 foreign nations (Masuda, 1977). With 200-mile limits, the conditions imposed on Japanese fishing by coastal nations are ever-increasing. These include entry fees, registration fees, fishing fees, quotas, excess catch fees, requests to expand the export of agricultural products to Japan, development cooperation, and joint ventures which the Japanese might consider marginal.

Japanese goals for distant-water tuna fisheries correspond to four distinct interest groups: (1) consumers, (2) small- to medium-scale tuna fishermen (called Japanese fishermen in this report), (3) large-scale fishing and trading companies, processors, and other related industries (called Japanese traders in this report), and (4) the Japanese government. Each has different goals 


\section{TABLE I}

Tuna-fishing goals and constraints for Indonesia and Japan

\begin{tabular}{|c|c|}
\hline Indonesia & Japan \\
\hline Goals & Short-term goals \\
\hline 1. Food (nutrition) & 1. Economic efficiency \\
\hline 2. Employment* & 2. Tuna supply * \\
\hline 3. Foreign exchange * & 3. Full utilization of existing fleet \\
\hline \multicolumn{2}{|l|}{ 4. Regional development } \\
\hline 5. Increase in Gross Domestic & 4. Employment * \\
\hline Product & 5. Fishermen's profit * \\
\hline 6. Fishermen's income & 6. Traders' profit $*$ \\
\hline 7. Return on investment * & 7. Return on investment * \\
\hline Sub-goals & Long-term goals \\
\hline 1. Technology transfer and training * & 1. Development of coastal fisheries \\
\hline 2. Stability of catch & 2. Development of high-sea fisheries \\
\hline 3. Conservation of resources & 3. Development of underutilized species use \\
\hline 4. Minimization of cost & $\begin{array}{l}\text { 4. Dietary change from tuna to other animal } \\
\text { products } \\
\text { 5. Resource enhancement } \\
\text { 6. Transfer of technology to developing countries } \\
\text { 7. Development of regional integration } \\
\text { 8. Gradual adjustment to economic dislocation } \\
\text { caused by } 200 \text {-mile limits }\end{array}$ \\
\hline Constraints & Constraints \\
\hline 1. Infrastructure & 1. Regulations and agreements \\
\hline 2. Capital * & 2. Fish resources \\
\hline 3. Fishing experience & 3. Minimum rate of return on investment \\
\hline 4. Socio-political aspects & 4. Bait availability \\
\hline 5. Fish resources & 5. Affordable fishing fees \\
\hline \multirow{4}{*}{ 6. Surveillance and enforcement } & 6. Labor \\
\hline & 7. Fuel price \\
\hline & 8. Incoherent bilateral arrangements \\
\hline & 9. Nationalization by coastal states \\
\hline
\end{tabular}

* Selected for detailed analysis.

and constraints (Ouchi and Matsuda, 1981).

Japanese consumers want a reliable supply of high-quality tuna at reasonable prices. In the face of many factors leading to higher tuna prices, the best way to maintain reasonable prices is to ensure an adequate supply.

Most Japanese fishermen are members of tuna fisheries cooperative associations or small- to medium-sized companies which supply more than 96\% of the total Japanese tuna catch. As their livelihood depends on tuna fisheries, they have had difficulties adjusting to the proliferation of restric- 
TABLE II

Tuna-fishery goals and operational definitions used in this study

\begin{tabular}{|c|c|}
\hline Item & Operational definition \\
\hline Capital investment (I) & Indonesian investment requirement (dollars/ton) \\
\hline Return on investment (I) & $\begin{array}{l}\text { Gross value to Indonesia minus total cost to Indonesia } \\
\text { (excluding interest) divided by Indonesian capital investment }\end{array}$ \\
\hline Employment (I) & Indonesian employment (man-years/ton) \\
\hline Foreign exchange (I) & $\begin{array}{l}\text { Gross value to Indonesia including fee or } 1 / 2 \text { export tax for } \\
\text { joint-venture (dollars/ton) }\end{array}$ \\
\hline Technology transfer $(I)$ & $\begin{array}{l}\text { Number of trainees } \times \text { training period } \times \text { weighting factor }(\text { dol- } \\
\text { lars } / \text { ton) }\end{array}$ \\
\hline Capital investment $(\mathrm{J})$ & Japanese investment requirement (dollars/ton) \\
\hline Return on investment $(\mathrm{J})$ & $\begin{array}{l}\text { Gross value to Japan minus total cost to Japan (including } \\
\text { export tax and fee, excluding interest) divided by Japanese } \\
\text { capital investment }\end{array}$ \\
\hline Employment $(\mathrm{J})$ & Employment of Japanese fishermen (man-years/ton) \\
\hline Tuna supply to Japan $(\mathrm{J})$ & Tuna supply to Japan $\times$ Japanese port prices (dollars/ton) \\
\hline Fishermen's profits $(\mathbf{J})$ & $\begin{array}{l}\text { Gross value to Japanese fishermen minus total cost to } \\
\text { Japanese fishermen (dollars/ton) }\end{array}$ \\
\hline Trader's profits $(\mathbf{J})$ & $\begin{array}{l}\text { Gross value to Japanese traders minus total cost to Japanese } \\
\text { traders (dollars/ton) }\end{array}$ \\
\hline
\end{tabular}

I represents Indonesia; J represents Japan; tons are wet weight of catch.

tions placed on their fishing by 200-mile limits. The tuna longline fishery experienced a comfortable growth during the 1960s, during which the industry established an extensive infrastructure all over the world.

By the 1970s, Japanese fishermen were confronted with low catches per unit effort and consequent overcapitalization. General inflationary trends, rising labor costs, increasing fuel prices, increasing competition with tuna fleets from Taiwan and Korea, a depressed domestic economy due to oil crises and environmental concerns, and the advent of the 200-mile limits have combined to weaken these small- or medium-sized enterprises. Since they cannot accumulate enough capital for joint fishing ventures that would help coastal states to develop their own fisheries, there are not many choices for Japanese fishermen but to continue fishing for their survival. In recent years, the Japanese tuna longline fishery has been confronted with a series of oil crises involving not only higher fuel prices, but problems of access to fuel, 
such that the survival of the present energy-intensive style of fishing is in question. Although Japanese tuna fishermen have integrated horizontally by forming fishing cooperatives there is also pressure for vertical integration (including processing and marketing) to minimize transaction costs which make up a substantial portion of the marketing margin.

Japanese traders are the most prominent tuna joint-venture partners. They are not only able to handle joint ventures financially, but they actually prefer joint-venture arrangements to fee fishing because their marketing role in joint venture presents the most attractive investment opportunity. Most of these trading companies are new to tuna fishing, but are assuming an expanding role. Although much of their capital is borrowed, their resources are relatively mobile. They are attracted to ventures providing higher rates of return on capital investment than other available prospects. The profits, however, need not always be direct or immediate. It may be satisfactory to the trading company if profits develop once the venture has grown to maturity.

Tuna fisheries in Japan represent a unique distant-water fishing system that has grown out of the traditional subsistence fishery with the encouragement of government licensing schemes. The Japanese government is responsible for two areas of national concern: first, facilitating a smooth transition through economic dislocations caused by 200 -mile limits; second, promoting international cooperation.

The success of the Japanese tuna fishing fleet has been threatened by the limited flexibility of the industry to respond to constraints imposed by 200-mile limits, due to overcapitalization, cost inflation, and difficulties in relocating displaced fishermen or transferring them to fishing other species. Current trends in Japanese tuna fisheries are not encouraging and may lead to drastic cutbacks. At the same time, the demand for Japanese fishing technology is increasing as coastal states try to develop their own fisheries. Satisfying this demand is a question of transferring Japanese technology to developing countries while gradually reducing the scale of Japanese fishing in those areas.

Indonesian perspective. Since the government of Indonesia is owner of all fishery resources within the jurisdictional limits of the country, the goals of development and management of those resources are national, i.e., social goals. Economic considerations such as profit are also significant, however, since the state cannot be expected to take on an enterprise which will lose money. The goals of Indonesia in developing the tuna fishery under its jurisdiction are as follows.

Indonesia needs foreign exchange to meet the needs of its development program. The more the country can produce and sell abroad, the greater its 
capacity as a nation to earn critical foreign exchange and the less will be its dependence on borrowed foreign capital. The large tunas represent important sources of foreign exchange through sales in Japan, the United States, and Western Europe.

One of the important development goals of Indonesia is to raise the levels of income and employment of its citizens, especially those disadvantaged by being far from the production centers and markets in heavily populated areas of the country. Eastern Indonesia is one such area with substantial resources of underexploited tuna. Development of a tuna fishery can assist in promoting income and employment in two ways: (a) by transferring small-scale fishermen from relatively low earning artisanal fisheries to the higher earning tuna fishery; and (b) by developing fish processing and distribution facilities which can absorb underemployed labor on the shore.

The government also wishes to foster technology transfer from prospective foreign users of Indonesia's resources to improve and advance the technical skills of Indonesian nationals. Development of tuna resources within the jurisdiction of Indonesia, in cooperation with foreign enterprise, can provide a mechanism for training and improving the skills of Indonesian managers of fishing enterprises and of fishermen.

Another national goal of the government of Indonesia is to raise the per capita level of fish consumption in the country from the present level of around $10 \mathrm{~kg}$ per capita per year to a more adequate nutritional level of around $30 \mathrm{~kg}$ per capita per year. This, however, cannot be done through direct development of tuna resources because the large tunas do not have a significant market in Indonesia in the near term. It can only be done indirectly by developing highly-trained fishermen in modern methods of fish harvesting techniques that can be used as a demonstration effect to develop other fisheries for domestic consumption. The foreign exchange from tuna sales could also be used to purchase other kinds of fish from abroad.

Finally, Indonesia has an interest in conserving and sustaining its tuna stocks so it can benefit from them in the future. Pursuant to this interest, it has goals to establish sound fishery management procedures and enforce them.

\section{Fishery arrangements}

The different possible arrangements between Indonesia and Japan were classified with regard to: (1) who participates in the fishing (Indonesians, Japanese, or joint ownership); (2) the type of processing (cold storage, canning, or freezer-carrier); (3) who participates in the processing (Indonesia, Japan or joint ownership). 
The characteristics of fishing and processing operations are shown in tables III and IV, respectively.

Fishing operations. It was assumed fishing operations with Japanese ownership would be similar to what Japanese fishermen employed in the Banda Sea during the treaty period. It was assumed fishing operations with Indonesian ownership would be similar to existing pole-and-line tuna fishing by Indonesians in their state enterprise, though operations based on larger boats (100-200 GT capacity) are a possibility, as Indonesia's state tuna longline enterprise has demonstrated.

For joint-ventures, type A fishing was based on small, low-capital vessels that Japanese coastal fishermen have used for many years. Type B joint venture fishing was based on the vessels assumed for Indonesian ownership; and Type $\mathrm{C}$ was based on the vessels for Japanese ownership.

Processing operations. Four basic processing alternatives were considered: no processing, cold storage, canning, and freezer-carrier. No processing refers to the kind of longline tuna fishing employed in the Banda Sea in recent years, where fish are transported to market in the same vessel that catches them.

If we had been dealing with fish that could be considered seriously for domestic consumption, it would have been necessary to specify whether the fish are consumed locally or exported. However, we considered only arrangements leading to export and assumed that marketing considerations after the fishermen or processors sold the tuna were beyond the scope of our study. Indonesian-based fishing activities were assumed to lead to sales from Indonesia's fresh fish market to international traders or processors.

A higher value was added when fishing activities were combined with processing. Canned goods were assumed for sale in non-Japanese markets. Frozen fish were assumed to be sold on international markets. Freezer-carrier operations involve the transfer of fish from the fishing vessel to a mother ship that freezes the fish and carries them to a foreign market. A freezer-carrier is therefore a floating base in contrast with the onshore bases in other processing operations. It was assumed that Indonesian freezer-carriers (600 tons) could travel only between the Banda Sea and transshipment ports in Southeast Asia, while joint-venture or Japanese-owned freezer-carriers (1200 tons) could travel between the Banda Sea and Japan to market the fish directly in Japan.

Ownership. We considered three ownership modes (Indonesian, joint-venture, and Japanese) for fishing and for processing. Indonesian capital may include capital borrowed from organizations such as the World Bank or the Asian Development Bank but not from Japanese fishermen or traders. 
TABLE III

Characteristics of fishing operations

\begin{tabular}{|c|c|c|c|c|c|c|c|c|}
\hline \multirow[t]{2}{*}{ Type } & \multirow{2}{*}{$\begin{array}{l}\text { Boat } \\
\text { size } \\
\text { (tons) }\end{array}$} & \multirow{2}{*}{$\begin{array}{l}\text { Capital } \\
\text { investment }\end{array}$} & \multicolumn{2}{|c|}{ Employment } & \multirow{2}{*}{$\begin{array}{l}\text { Gross } \\
\text { value }\end{array}$} & \multirow{2}{*}{$\begin{array}{l}\text { Return on } \\
\text { investment }\end{array}$} & \multirow{2}{*}{$\begin{array}{l}\text { Technology } \\
\text { transfer }\end{array}$} & \multirow{2}{*}{$\begin{array}{l}\text { Food } \\
\text { for } \\
\text { Japan }\end{array}$} \\
\hline & & & Japan & Indonesia & & & & \\
\hline Indonesia & 30 & medium & 0 & high & low & negative & medium & 0 \\
\hline $\begin{array}{l}\text { Joint } \\
\text { venture (A) }\end{array}$ & 20 & medium & medium & medium & low & negative & medium & 0 \\
\hline $\begin{array}{l}\text { Joint } \\
\text { venture (B) }\end{array}$ & 30 & medium & 0 & medium & low & negative & medium & 0 \\
\hline $\begin{array}{l}\text { Joint } \\
\text { venture (C) }\end{array}$ & 80 & high & medium & medium & low & $\begin{array}{l}\text { very } \\
\text { negative }\end{array}$ & high & 0 \\
\hline Japan & 80 & $\begin{array}{l}\text { very } \\
\text { high }\end{array}$ & high & 0 & high & low & low & high \\
\hline
\end{tabular}




\section{TABLE IV}

Characteristics of processing operations

\begin{tabular}{|c|c|c|c|c|c|c|c|c|}
\hline \multirow[t]{2}{*}{ Operation } & \multirow[t]{2}{*}{ Ownership } & \multirow{2}{*}{$\begin{array}{l}\text { Capital } \\
\text { investment }\end{array}$} & \multicolumn{2}{|c|}{ Employment } & \multirow{2}{*}{$\begin{array}{l}\text { Gross } \\
\text { value }\end{array}$} & \multirow{2}{*}{$\begin{array}{l}\text { Return on } \\
\text { investment }\end{array}$} & \multirow{2}{*}{$\begin{array}{l}\text { Technology } \\
\text { transfer }\end{array}$} & \multirow{2}{*}{$\begin{array}{l}\text { Food } \\
\text { for } \\
\text { Japan }\end{array}$} \\
\hline & & & Japan & Indonesia & & & & \\
\hline \multirow[t]{2}{*}{$\begin{array}{l}\text { Cold } \\
\text { storage }\end{array}$} & Indonesia & medium & 0 & $\begin{array}{l}\text { very } \\
\text { low }\end{array}$ & medium & medium & medium & 0 \\
\hline & $\begin{array}{l}\text { joint } \\
\text { venture/Japan }\end{array}$ & medium & $\begin{array}{l}\text { very } \\
\text { low }\end{array}$ & $\begin{array}{l}\text { very } \\
\text { low }\end{array}$ & medium & medium & low & $\begin{array}{l}\text { high } \\
0\end{array}$ \\
\hline Canning & $\begin{array}{l}\text { Indonesia } \\
\text { joint } \\
\text { venture/Japan }\end{array}$ & $\begin{array}{l}\text { high } \\
\text { high }\end{array}$ & $\begin{array}{l}0 \\
\text { very } \\
\text { low }\end{array}$ & $\begin{array}{l}\text { medium } \\
\text { medium }\end{array}$ & $\begin{array}{l}\text { high } \\
\text { high }\end{array}$ & $\begin{array}{l}\text { medium } \\
\text { medium }\end{array}$ & $\begin{array}{l}\text { medium } \\
\text { low }\end{array}$ & $\begin{array}{l}0 \\
0\end{array}$ \\
\hline \multirow{2}{*}{$\begin{array}{l}\text { Freezer- } \\
\text { carrier }\end{array}$} & Indonesia & low & 0 & low & medium & medium & medium & 0 \\
\hline & $\begin{array}{l}\text { joint } \\
\text { venture/Japan }\end{array}$ & $\begin{array}{l}\text { very } \\
\text { low }\end{array}$ & low & low & $\begin{array}{l}\text { very } \\
\text { high }\end{array}$ & $\begin{array}{l}\text { very } \\
\text { high }\end{array}$ & low & high \\
\hline
\end{tabular}


Direct marketing by Indonesia in Japan was not allowed.

Joint-venture ownership in this report refers to an enterprise with 50/50 capital sharing between Indonesian and Japanese partners, profit being shared the same way. Although many kinds of joint-venture fishing arrangements would be possible, we examined three in detail (Table III), all of them involving Indonesian-based fishing vessels. Types $\mathrm{A}$ and $\mathrm{C}$ joint-venture fishing include the participation of Japanese fishermen and Type B does not. Joint-venture processing includes Japanese traders and Japanese small- or medium-scale tuna fishermen. Aside from canned goods, all fish under joint-venture processing were assumed to go to Japanese markets in the form of frozen fish.

Japanese ownership refers to an enterprise with $100 \%$ Japanese capital, which may include capital borrowed from the Japanese government. Within this framework, it was assumed only Japanese fishermen were involved in the fishing part and Japanese traders in the processing part. Aside from canned goods, all fish under Japanese processing were assumed to go to Japanese markets in the form of frozen fish.

\section{Goal values of fishery arrangements}

A goal value is the unit cost or benefit of a particular arrangement with respect to a particular goal, for example the amount of Indonesian employment generated by producing one ton of fish with Indonesian fishing and Japanese canning. There are 60 possible fishery arrangements $(5$ kinds of fishing $\times 4$ kinds of processing $\times 3$ processing ownerships), and we calculated goal values for 37 of the arrangements, which we considered most feasible. Table $\mathrm{V}$ presents the goal values we assigned to the 37 arrangements. Marten et al. (1981) have presented a detailed documentation of these values based on the costs of different kinds of fishing and processing operations and the prices commanded by the fish in different kinds of markets. Most of the data came from the Japanese Ministry of Agriculture, Forestry, and Fisheries (Japanese Fishery Agency, 1970-1979) and personal knowledge of team members.

Tables III and IV summarize the effectiveness of the different operations that might go into an arrangement. (We will postpone for the moment the question of how ownership, costs and benefits might be distributed between Indonesia and Japan.) Canneries require the most capital and freezer-carriers the least capital, particularly if Japan is involved in operating the freezer-carriers. The employment generated by processing is substantially less than the employment generated by fishing and varies considerably with the kind of processing, being greatest for canning and least for cold storage. 
TABLE V

Goal values of fishery arrangements

\begin{tabular}{|c|c|c|c|c|c|c|c|c|}
\hline \multirow{2}{*}{$\begin{array}{l}\text { Satisfactory } \\
\text { return on } \\
\text { investment } \\
\text { for: }\end{array}$} & \multicolumn{3}{|l|}{ Arrangement } & \multicolumn{5}{|l|}{ Indonesia } \\
\hline & $\begin{array}{l}\text { fishing } \\
\text { owner }\end{array}$ & $\begin{array}{l}\text { processing } \\
\text { owner }\end{array}$ & $\begin{array}{l}\text { processing } \\
\text { type }\end{array}$ & $\begin{array}{l}\text { capital } \\
\text { invest } \\
\text { ment } \\
\text { (dollars / } \\
\text { (ton) }\end{array}$ & $\begin{array}{l}\text { return on } \\
\text { invest } \\
\text { ment } \\
\text { (percent) }\end{array}$ & $\begin{array}{l}\text { employ- } \\
\text { ment (man- } \\
\text { years/ton) }\end{array}$ & $\begin{array}{l}\text { foreign } \\
\text { exchange } \\
\text { (dollars/ } \\
\text { ton) }\end{array}$ & $\begin{array}{l}\text { technology } \\
\text { transfer } \\
\text { (dollars / } \\
\text { ton) }\end{array}$ \\
\hline Both & Indonesia & Joint-venture & freezer-carrier & 847 & 77 & 0.021 & 1465 & 99 \\
\hline Indonesia & Joint-venture (A) & Joint-venture & cold storage & 842 & 24 & 0.015 & 569 & 128 \\
\hline \multirow[t]{6}{*}{ and Japan } & Joint-venture (A) & Joint-venture & canning & 1061 & 25 & 0.024 & 770 & 128 \\
\hline & Joint-venture (A) & Joint-venture & freezer-carrier & 517 & 127 & 0.017 & 1232 & 116 \\
\hline & Joint-venture (B) & Joint-venture & cold storage & 805 & 29 & 0.014 & 569 & 111 \\
\hline & Joint-venture (B) & Joint-venture & canning & 1024 & 29 & 0.024 & 770 & 111 \\
\hline & Joint-venture (B) & Joint-venture & freezer-carrier & 480 & 143 & 0.017 & 1232 & 99 \\
\hline & Joint-venture (C) & Joint-venture & freezer-carrier & 800 & 35 & 0.013 & 1232 & 473 \\
\hline \multirow[t]{6}{*}{ Indonesia } & Indonesia & Indonesia & cold storage & 1610 & 23 & 0.019 & 1019 & 130 \\
\hline & Indonesia & Indonesia & canning & 2049 & 23 & 0.029 & 1385 & 130 \\
\hline & Joint-venture (A) & Indonesia & cold storage & 1281 & 27 & 0.015 & 762 & 147 \\
\hline & Joint-venture (A) & Indonesia & canning & 1719 & 26 & 0.025 & 1128 & 147 \\
\hline & Joint-venture (B) & Indonesia & cold storage & 1244 & 30 & 0.015 & 762 & 130 \\
\hline & Joint-venture (B) & Indonesia & canning & 1682 & 28 & 0.024 & 1128 & 130 \\
\hline
\end{tabular}




\begin{tabular}{|c|c|c|c|c|c|c|c|c|}
\hline \multirow[t]{12}{*}{ Japan } & Indonesia & Joint-venture & cold-storage & 1172 & 17 & 0.019 & 802 & 111 \\
\hline & Indonesia & Joint-venture & canning & 1391 & 19 & 0.028 & 1004 & 111 \\
\hline & Indonesia & Japan & cold storage & 733 & -11 & 0.019 & 467 & 83 \\
\hline & Indonesia & Japan & canning & 733 & -11 & 0.028 & 467 & 83 \\
\hline & Indonesia & Japan & freezer-carrier & 733 & -11 & 0.018 & 467 & 69 \\
\hline & Joint-venture (A) & Japan & cold storage & 404 & -12 & 0.015 & 261 & 100 \\
\hline & Joint-venture (A) & Japan & canning & 404 & -12 & 0.024 & 261 & 100 \\
\hline & Joint-venture (A) & Japan & freezer-carrier & 404 & -12 & 0.014 & 261 & 86 \\
\hline & Joint-venture (B) & Japan & cold storage & 367 & -5 & 0.014 & 261 & 83 \\
\hline & Joint-venture (B) & Japan & canning & 367 & -5 & 0.024 & 261 & 83 \\
\hline & Joint-venture (B) & Japan & freezer-carrier & 367 & -5 & 0.014 & 261 & 69 \\
\hline & Japan & Japan & freezer carrier & 0 & - & 0 & 91 & 29 \\
\hline \multirow{11}{*}{$\begin{array}{l}\text { Neither } \\
\text { country }\end{array}$} & Indonesia & Indonesia & no processing & 733 & -10 & 0.018 & 0 & 69 \\
\hline & Indonesia & Indonesia & freezer-carrier & 1366 & 13 & 0.021 & 1019 & 121 \\
\hline & Joint-venture (A) & Indonesia & freezer-carrier & 1027 & 16 & 0.017 & 762 & 138 \\
\hline & Joint-venture (B) & Joint-venture & no processing & 367 & -5 & 0.014 & 261 & 69 \\
\hline & Joint-venture (B) & Indonesia & freezer-carrier & 990 & 19 & 0.016 & 762 & 121 \\
\hline & Joint-venture (C) & Indonesia & cold storage & 1563 & -2 & 0.011 & 769 & 104 \\
\hline & Joint-venture (C) & Indonesia & canning & 2002 & 4 & 0.021 & 1135 & 104 \\
\hline & Joint-venture (C) & Indonesia & freezer-carrier & 1310 & -16 & 0.013 & 769 & 95 \\
\hline & Joint-venture (C) & Joint-venture & cold storage & 1125 & -16 & 0.011 & 569 & 485 \\
\hline & Joint-venture (C) & Joint-venture & canning & 1344 & -8 & 0.021 & 770 & 485 \\
\hline & Japan & Japan & no processing & 0 & - & 0 & 91 & 43 \\
\hline
\end{tabular}


TABLE V (continued)

\begin{tabular}{|c|c|c|c|c|c|c|}
\hline \multirow{2}{*}{$\begin{array}{l}\text { Satisfactory } \\
\text { return on } \\
\text { investment } \\
\text { for: }\end{array}$} & \multicolumn{6}{|l|}{ Japan } \\
\hline & $\begin{array}{l}\text { capital } \\
\text { investment } \\
\text { (dollars / } \\
\text { ton) }\end{array}$ & $\begin{array}{l}\text { return on } \\
\text { investment } \\
\text { (percent) }\end{array}$ & $\begin{array}{l}\text { food for } \\
\text { Japan } \\
\text { (dollars / } \\
\text { ton) }\end{array}$ & $\begin{array}{l}\text { employment } \\
\text { of fishermen } \\
\text { (man-years/ } \\
\text { ton) }\end{array}$ & $\begin{array}{l}\text { fishermen's } \\
\text { profits } \\
\text { (dollars / } \\
\text { ton) }\end{array}$ & $\begin{array}{l}\text { trader's } \\
\text { profits } \\
\text { (dollars / } \\
\text { ton) }\end{array}$ \\
\hline \multirow{8}{*}{$\begin{array}{l}\text { Both } \\
\text { Indonesia } \\
\text { and Japan }\end{array}$} & 113 & 638 & 2427 & 0 & 0 & 713 \\
\hline & 842 & 24 & 2427 & 0.017 & 59 & 59 \\
\hline & 1061 & 25 & 0 & 0.017 & 81 & 81 \\
\hline & 517 & 127 & 2427 & 0.017 & 302 & 302 \\
\hline & 805 & 29 & 2427 & 0 & 0 & 151 \\
\hline & 1024 & 29 & 0 & 0 & 0 & 196 \\
\hline & 480 & 143 & 2427 & 0 & 0 & 639 \\
\hline & 800 & 35 & 2427 & 0.017 & 99 & 99 \\
\hline \multirow[t]{6}{*}{ Indonesia } & 0 & - & 0 & 0 & 0 & 0 \\
\hline & 0 & - & 0 & 0 & 0 & 0 \\
\hline & 404 & -11 & 0 & 0.017 & -84 & 0 \\
\hline & 404 & -11 & 0 & 0.017 & -84 & 0 \\
\hline & 404 & -4 & 0 & 0 & 0 & -50 \\
\hline & 367 & -4 & 0 & 0 & 0 & -50 \\
\hline \multirow[t]{2}{*}{ Japan } & 438 & 61 & 2427 & 0 & 0 & 225 \\
\hline & 658 & 51 & 0 & 0 & 0 & 269 \\
\hline
\end{tabular}




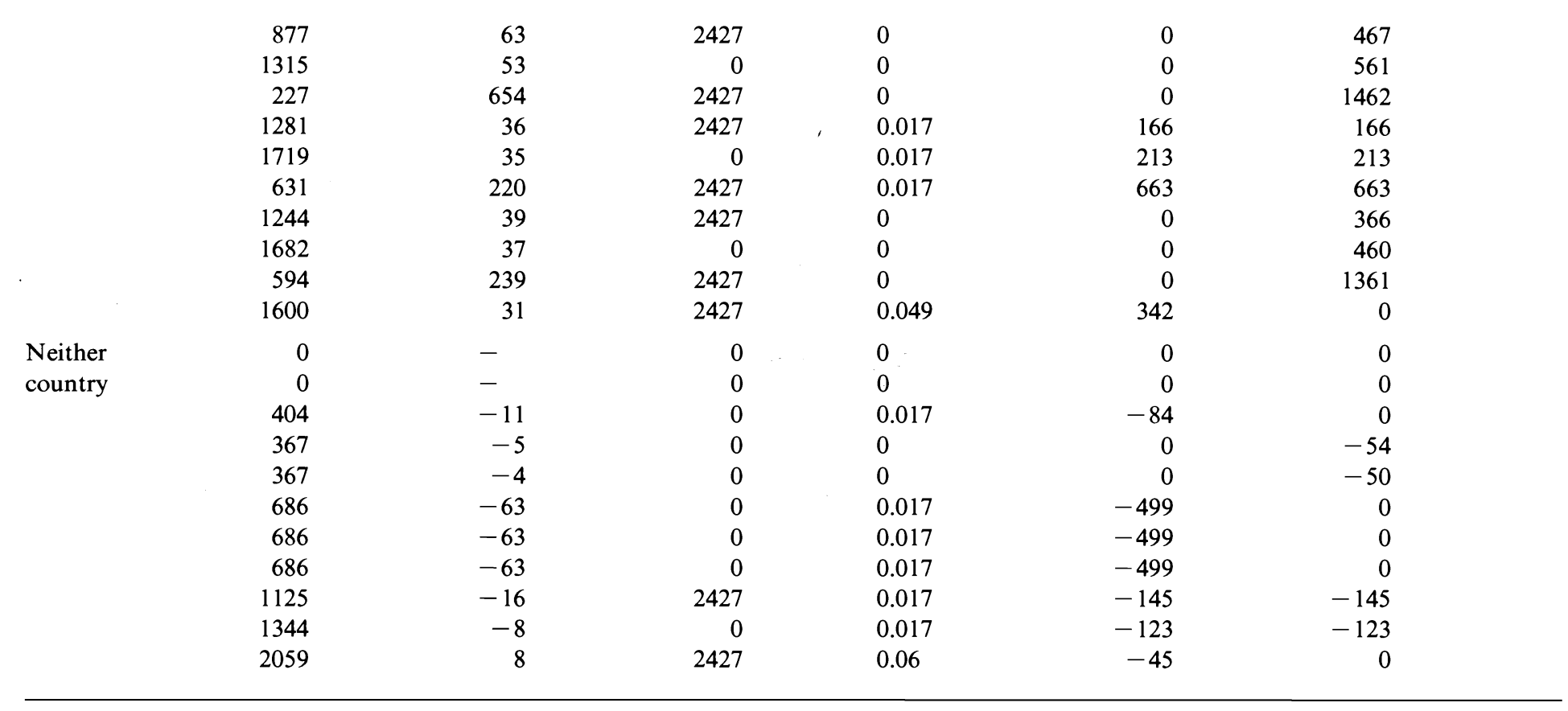


Gross value is important as potential foreign exchange for Indonesia, and when used to generate employment, as the source of income for fishing and processing workers. The gross value from fishing alone is not very great. It is increased immensely, however, by transporting the fish to Japan or by some other form of processing which adds value to the fish by putting them in a form suitable for the international market. Although there is a slight progression in value as one passes from cold storage to canning, the greatest gross value can be realized by carrying the fish by freezer-carrier to Japan.

The amount of technology transfer in processing is generally lower than in fishing even though some processing such as canning has relatively higher employment. This is mainly because in processing joint ventures most jobs for Indonesians would not be the kind of managerial jobs that lead to much technology transfer. In contrast, technology transfer in joint-venture fishing can be high because of the greater ease of Indonesian participation at all levels.

Both employment and profits compete for the gross value that is obtained, and in general, an operation that generates a high level of employment has higher operating costs and less profits. Higher employment generated by fishing can significantly limit the profits in the overall fishing and processing operation. All of the processing operations show a net profit, in the range of $40-60 \%$ for cold storage and canning, and as high as $600 \%$ for freezer-carrier operations. Profits from fishing alone are generally negative.

\section{RESULTS}

\section{Performance of fishery arrangements}

We will now evaluate the 37 arrangements in Table $\mathrm{V}$ in view of the costs and benefits they would provide for Indonesia and Japan. The goal values in Table $\mathrm{V}$ are only approximations because the fish prices and fishing costs on which they are based fluctuate from year to year. There is no single arrangement which is best for all goals. If we consider first the Indonesian perspective and focus on Indonesian goals of high employment, foreign exchange, and technology transfer while keeping in mind the need for moderate demands on capital and an acceptable rate of return on investment (assumed to be 20\%), only 14 of the 37 arrangements satisfy these conditions. Considering only these 14 arrangements, Indonesian fishing with Indonesian canning can generate the most employment for Indonesia, while both this arrangement and Indonesian fishing with joint-venture freezer-carrier processing generate the highest foreign exchange earnings. In contrast, 
the best technology transfer comes from Type $C$ joint-venture fishing combined with freezer-carrier joint-venture processing.

With exclusively Indonesian ownership, the rates of return on investment are at best moderate (23\%). In fact, all arrangements except joint-venture freezer-carrier processing (which has high profits) show a return on investment of $30 \%$ or less for Indonesia. If all of Indonesia's goals are considered jointly, by adding their estimated dollar values, the best overall arrangement for Indonesia is Indonesian fishing with joint-venture freezer-carrier processing.

Turning to Japanese interests, which include food supply, fishermen's employment, and profits, 20 arrangements provide an acceptable rate of return, assumed to be $15 \%$ or more. Considering only those 20 arrangements, the greatest food supply for Japan is provided by any kind of fishing combined with cold storage or freezer-carrier processing in which Japan has a part. The greatest employment for Japanese fishermen is of course generated by exclusively Japanese fee fishing, but next to that, the greatest Japanese employment is found in Type A joint-venture fishing. Type A joint-venture fishing, combined with joint-venture freezer-carriers also gives the highest profits to Japanese fishermen. In contrast, the highest profits to traders come from Indonesian or Type B joint-venture fishing with Japanese freezer-carriers. If all Japanese goals are considered simultaneously in terms of dollar values, the best overall arrangement for Japan is Indonesian fishing with Japanese freezer-carrier processing.

Of the 37 arrangements, 8 provide an acceptable return on investment for both Indonesia and Japan (Table V). Joint-venture freezer-carrier processing combined with joint-venture fishing (type A or B) or Indonesian fishing are the best solutions among these according to rates of return on capital. If all high-priority goals of Indonesia and Japan are considered jointly in terms of dollar values, the best overall arrangement for both Indonesia and Japan is Indonesian fishing with joint-venture freezer-carrier processing. Thus, as long as there are no constraints, Indonesian fishing appears to be the best overall option for both nations. Freezer-carrier processing also appears the best option for both nations, although it is better for Japan to operate alone and better for Indonesia in a joint venture. There is, however, one major defect in these best arrangements: Indonesian fishing would not employ Japanese fishermen who have been fishing the Banda Sea under recent fee-fishing agreements.

\section{Limited Indonesian capital}

Because Indonesia has many development programs placing demands on its limited capital, it is realistic to consider the implications of limited 
capital. We used goal programming to identify optimal mixes of fishing and processing arrangements with a constraint on Indonesian capital (Fig. 2). Goal programming is an extension of linear programming which has the capacity to deal with multiple objectives (Lee, 1972).

Referring to Fig. 2, Japanese fee fishing should be replaced by Indonesian-owned fishing to the extent that Indonesian capital allows, using joint-venture fishing as a transition. However, the best joint venture is type A for Japan and type B for Indonesia. While both types of fishing perform equally with respect to Indonesian employment and foreign exchange, jointventure type B fishing not only requires less capital for Indonesia than type A but produces more profit. For Japan, joint-venture type A fishing improves Japanese employment, although Japanese fishermen would realize negative profits.

From the Indonesian (and mutual) point of view, processing should be joint-venture freezer-carrier to the extent that Indonesian capital allows, with the remainder being exclusively Japanese (Fig. 2). From the Japanese point of view, Japanese freezer-carriers are best regardless of the availability of Indonesian capital.

If the interests of both countries are considered simultaneously (Fig. 2), an increase in Indonesian capital should lead to a replacement of fee-fishing by joint-venture type $\mathrm{B}$, which in turn is replaced by joint-venture type $\mathrm{A}$, and finally Indonesian fishing. The sample solution in Fig. 2 has joint-venture type B fishing phasing in at a lower capital investment than joint-venture type A, apparently because Type B requires slightly less Indonesian capital than type A. However, a smooth transition in phasing out Japanese fishermen would suggest Japanese fee-fishing should be followed by a type A joint venture before proceeding to type B as Indonesian capital increases. Type A provides better technology transfer for Indonesia and better fishermen employment for Japan, although at the expense of profits for the fishing sectors of both countries. Fortunately, once fishing is combined with jointventure freezer-carriers, the negative aspects of the fishing sector are substantially compensated by freezer-carrier profits, such that all interest groups enjoy reasonable profits.

For all interests, Indonesian fishing replaces joint-venture fishing in Fig. 2 as the best arrangement when Indonesian capital becomes great enough to no longer limit the choices. Although Indonesian fishing has a higher capital requirement for Indonesia, it also provides higher employment and foreign exchange earnings for Indonesia and higher traders' profits for Japan when combined with joint-venture freezer-carrier operations. This arrangement, however, is not as good as some with respect to Indonesian total profits and technology transfer (though it is still quite satisfactory), and it is deficient in providing benefits for Japanese fishermen. 


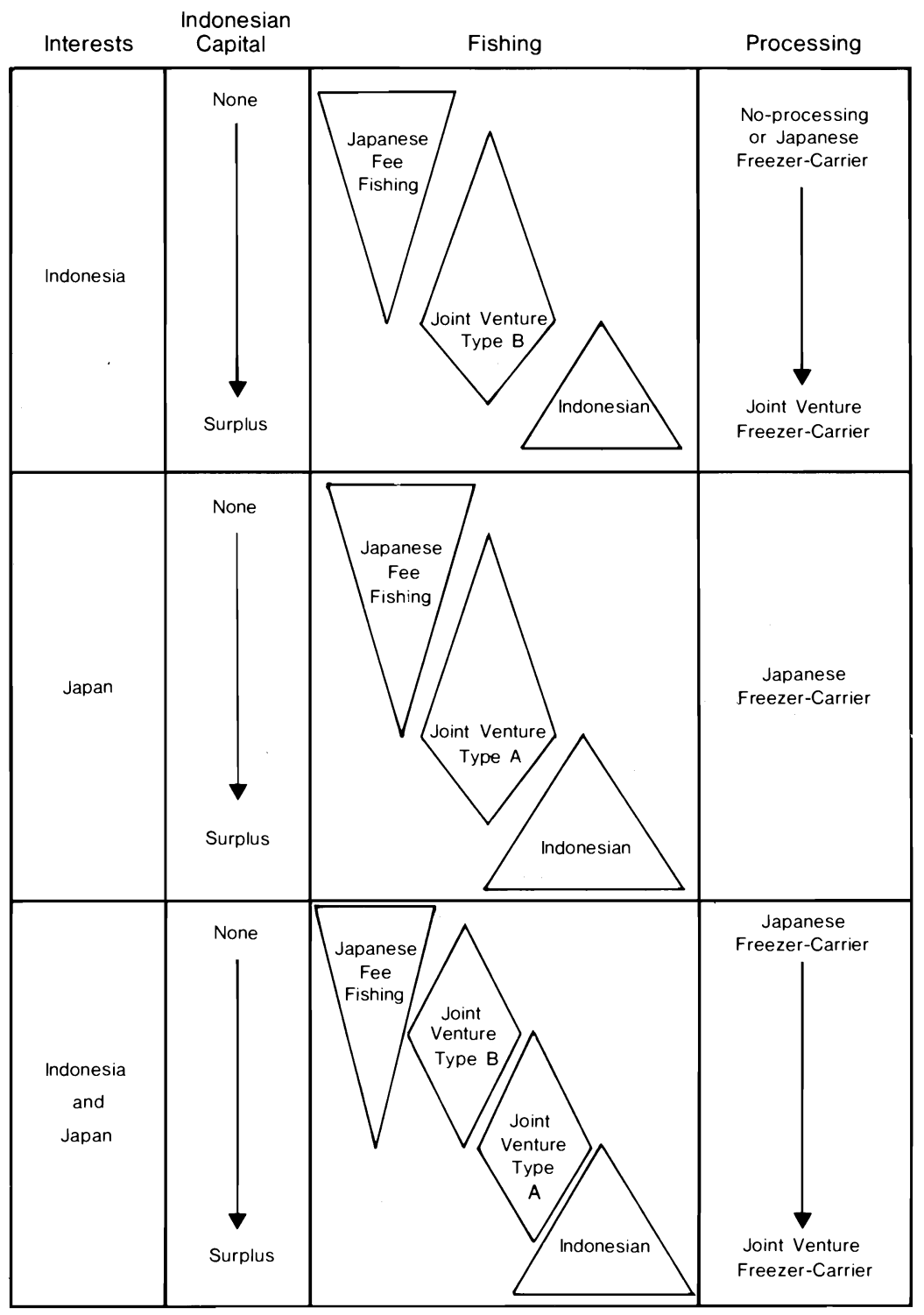

Japanese interests: Employment, food supply, fishermen's profits, and traders profits

Indonesian interests: Foreign exchange, employment, technology transfer, and total profits

Fig. 2. Optimal arrangements based on joint consideration of high-priority goals (with dollar weighting), using goal programming. Polygon width indicates the portion of the fishery which is exploited under each arrangment. 


\section{CONCLUSIONS}

Although the type of fee-fishing which was in operation during the past decade, generates more employment for Japanese fishermen than any other arrangement examined, fee-fishing is far from optimal for both Indonesia and Japan in other ways. It generates very little employment, foreign exchange, or technology transfer for Indonesia and is at best a marginal economic activity for Japan. If there is to be fee fishing, it would be economically more attractive to Japan if it were freezer-carrier fee-fishing, which was prohibited under the recent agreements.

Of the four processing options examined, only canning and freezer-carrier appear favorable enough to warrant serious consideration (see Table V). If Indonesia is operating the fishery alone, the best overall option is canning for European and North American markets. Canning provides the most local employment and adds the most value to the product, thereby generating higher foreign exchange earnings than other kinds of processing. Canning is, however, very undesirable if capital is limited or if supplying food to Japan is a high priority.

The other most attractive processing option for Indonesia, freezer-carrier processing, would give Indonesian fishermen employment by providing the opportunity to be involved in processing and expanding their marketing frontiers, even though the rate of return on capital might be marginal if Indonesia does it alone. Furthermore, if Indonesia should want to enter joint-venture freezer-carrier processing for the Japanese market, it would be financially more secure for Indonesia (in the sense of return on investment) than canning or freezer-carrier processing on their own. Freezer-carrier processing is also advantageous for Japan in providing an opportunity for profitable investments, employment for Japanese, and food for Japan in a form for which there is the most demand. It should be noted that these benefits to both Japan and Indonesia are gained at a cost to Indonesian employment, since freezer-carrier operations generate significantly less Indonesian employment than local canning. Although it might be best from a Japanese view for freezer-carrier operations to be run exclusively by Japan, a joint venture would be more equitable by allowing Indonesia to share in the profits that result from marketing the fish in Japan.

Considering the ownership of fishing, there is a tradeoff between profit and employment. Whereas fish marketing can be highly profitable, fishing itself is an economically marginal activity, though a necessary one to supply fish for any processing and marketing operation. To the extent one country or the other does the fishing, it increases its employment but diminishes the rate of return on its investment. Any real arrangement might therefore require negotiation of fish prices outside of market values, in order to make the arrangement equitable. 
Although we consider the results of this study to be basically sound, we also recognize its limitations. Our perspective may have been limited because we are scientists rather than fisheries negotiators, and our data tabulations were limited by the information available to us. We do not expect that negotiators will be able to mechanically select the "best" fisheries arrangement from this report. There are many considerations that negotiators must keep in mind even though those considerations cannot be quantified with the methodology we have suggested.

Conservation of the tuna stocks is one consideration we did not develop in this report. It is unfortunate that the biological information on tuna stocks is not sufficient to suggest stock management procedures to build international tuna fishing arrangements. At this point in time the best that can be done is to accumulate proper fisheries records and provide support for fisheries studies (such as tagging) by building records and research activities into the fishery arrangements, so the necessary biological information will eventually be forthcoming. The owner of the fishery resource has a vested interest in sustaining the resource and is in a strong bargaining position to see that distant-water fleets that want to share in the resource assist in gathering the biological information that will help to sustain it.

Our purpose in this report has been to demonstrate a format for tabulating and evaluating objective information so as to help negotiators appreciate the tradeoffs involved in alternative fisheries arrangements they are considering. Such information should help to narrow down the numerous possible arrangements to a smaller number that are satisfactory for all parties involved, allowing final selections from manageably few possibilities when subjective criteria must come into the process.

\section{ACKNOWLEDGEMENTS}

Mark Valencia, Coordinator of the East-West Environment and Policy Institute's project on Marine Environment and Extended Maritime Jurisdiction assembled the group which did this study.

Kazuomi Ouchi, Surna Djajadiningrat, and Virginia Aprieto collaborated in various stages of the study. Yoko Matsuda and Marina Chang assisted with compilation of the tables.

\section{REFERENCES}

Aprieto, V.L., 1981. Fisheries management and extended maritime jurisdiction: the Phillippine tuna fisheries situation. East-West Environ. Pol. Inst. Honolulu, Res. Rep., 4. 
Bardach, J.E. and Matsuda, Y., 1980. Fish, fishing, and sea boundaries: tuna stocks and fishing policies in Southeast Asia and the South Pacific. Geojournal, 4: 467-478.

Comitini, S., 1971. Licensing and efficiency: an empirical study of the Japanese tuna-fishing industry. Malay. Econ. Rev., 16: 76-83.

Djalal, H., 1978. Implementation of agreements with foreigners. Discuss. Pap. 2nd Comm. 3rd U.N. Conf. Law of the Sea.

Hara, H., 1979. Transition in the Japanese distant-water fishery. Mar. Affairs J., 6: 82-93.

Japan Fishery Agency, 1970-79. Annual Reports of Effort and Catch Statistics by Area on Japanese Tuna Longline Fishery 1968-77.

Kaczynski, W., 1979. Joint ventures in fisheries between distant-water and developed coastal nations. Ocean Manag., 5: 39-48.

Lee, S.M., 1972. Goal Programming for Decision Analysis. Petrocelli, New York.

Marten, G.G., Y. Matsuda, J. Bardach, S. Comitini, and S. Hardjolukito, 1981. A strategic goal analysis of options for tuna longline joint ventures in Southeast Asia: Indonesia-Japan case study. East-West Environ. Pol. Inst. Honolulu, Res. Rep., 3.

Masuda, S., 1963. Tuna and Skipjack Fishery. Suisan Sha, Tokyo.

Masuda, S., 1977. Tuna-skipjack fishery under the new 200-mile regime. Suisan Shuho, 796: 14-19.

Morisawa, M., 1980. Four-year-old fisheries under the 200-mile regime. Curr. Mar. Top ., 16: $35-47$.

Oamabara, H., 1962. A type of fishing ground use by fisheries licensing system: tuna skipjack fisheries. Gyogyo Keizai Kenkyu, 10: 28-45.

Ouchi, K. and Matsuda, Y., 1981. Legal, political and economic constraints in Japanese strategies for distant-water tuna fisheries in Southeast Asian seas and the Southwestern Pacific. (Submitted for publication as East-West Environment and Policy Institute Research Report, Honolulu.)

Valencia, M., 1979. South China Sea: present and potential coastal area resource use conflicts. Ocean Manage., 5: 1-38.

Zimbo, S. 1979. Fishing security of Japanese tuna longline vessels at the Banda Sea. Overseas Fisheries Cooperation Foundation. Foreign Fish. Coop., 19: 6-15. 